\title{
El pensamiento colonial*
}

* Matamoros, Fernando, El pensamiento colonial. Descubrimiento, conquista y "guerra de los dioses en México", México, BuAp-Universidad Veracruzana, 2015, 652 pp.

Tla-Melaua, revista de Ciencias Sociales. Facultad de Derecho y Ciencias Sociales. Benemérita Universidad Autónoma de Puebla, México / IssN: 1870-6916 / Nueva Época, Año 10, No 40, abril/septiembre 2016, pp. 208-210. 
Tengo la suerte de conocer a Fernando Matamoros desde hace varios años: primero, como militante político comprometido con la causa de los explotados; luego, como estudiante en la Escuela de Altos Estudios en Ciencias Sociales en París y, finalmente, como académico en la Benemérita Universidad Autónoma de Puebla, en México. Contrariamente a muchos, Fernando no ha abandonado sus sueños de juventud. La causa de los dominados, de los oprimidos, siempre inspira su trabajo como investigador científico, lo cual da a sus escritos una indiscutible calidad humana.

Como sabemos, Walter Benjamin pedía al historiador crítico escribir la historia "a contrapelo", en oposición a la historiografia oficial, siempre lista para celebrar emperadores, conquistadores y evangelizadores, en nombre de la marcha triunfal de la civilización. El acercamiento interdisciplinario de la sociología de las religiones, a la historia y a la antropología, nos hace descubrir el funcionamiento de esa ideología colonial con sus dimensiones mística, mesiánica, política y utópica.

El libro está inspirado por un punto de vista fuerte y consciente que le da unidad y coherencia. Este es el punto de vista de los indígenas, aquellos que a lo largo de siglos han sido descubiertos, conquistados, colonizados, convertidos, sojuzgados, exterminados. En este contexto, Matamoros Ponce aborda la historia con las mejores fuentes, desde Bartolomé de Las Casas hasta Nathan Wachtel, pasando por Octavio Paz y Enrique Dussel. Pero también recurre a Marx, para entender la Conquista y la Colonización como un capítulo del proceso de acumulación primitiva del capital:

El descubrimiento de las comarcas auríferas y argentíferas en América, el exterminio, esclavización y soterramiento en las minas de la población aborigen, la conquista y saqueo de las Indias orientales, la transformación de África en un coto reservado para la caza comercial de pieles negras, caracterizan los albores de la era de produccion capitalista. Estos procesos idílicos constituyen factores fundamentales de la acumulación originaria.

\footnotetext{
* Director de investigación emérito del Centro Nacional de Investigación Científica, Francia.
} 
La fuerza de convicción de Fernando Matamoros no ha perjudicado para nada la calidad científica de su trabajo. Su punto de vista, que parte desde los colonizados, no impide su atención, incluso fascinación, en los argumentos proféticos y milenaristas de los cuatro personajes emblemáticos de la Conquista: Colón, Cortés, Sahagún, Mendieta —el descubridor, el conquistador y los misioneros-.

Se trata de comprender, a través de un análisis interno del discurso, cómo los actores componen y recomponen sus identidades simbólicas e intentan legitimar su acción y empresa colonial. Aunque comparten todos los prejuicios del colonizador, hay diferencias notables entre el exterminador Cortés y el misionero Sahagún, maravillado por las civilizaciones indígenas.

Los paradigmas del pensamiento colonial perduran en Mexico y América Latina y nutren la imagen del indio bárbaro, salvaje e inculto, a quien se debe civilizar. Por esto, los debates sobre el des-cubrimiento y la Conquista no son simplemente historiográficos. Como lo vimos durante las confrontaciones en la ocasión del Quinto Centenario (1992): con el pasado, se actualizan fines políticos y sociales en el presente.

Mientras los gobiernos ibéricos y latinoamericanos, los banqueros, las jerarquías religiosas y los notables celebraban a Cristobal Colón y el encuentro entre civilizaciones, se formó un movimiento de protesta, resistencia de la memoria para recordar quinientos años de resistencia indígena, negra y popular, y para homenajear a fray Bartolomé de Las Casas, Cuauhtémoc y Túpac Amaru.

Los teólogos de la liberación, Enrique Dussel, Gustavo Gutiérrez e Ignacio Ellacuria, también tomaron posición en este debate. Este último, jesuita y rector de la Universidad Centroamericana de San Salvador, criticaba, en enero de 1989, la óptica grandilocuente de aquellos que se preparaban a celebrar "la gran hazaña" de 1492. El descubrimiento ha sido, al mismo tiempo, una ocultación: por la violencia se ha encubierto a los pueblos que habitaban las Américas, sus culturas, sus lenguas, sus personas. Ellacuria fue asesinado por los militares de su país en noviembre de 1989.

No es casualidad que el Ejército Zapatista de Liberación Nacional (EZLN) haya previsto su levantamiento en 1992, como acto simbólico de rebeldía contra esos cinco siglos de opresión. Optaron por aplazar su insurrección y se limitaron a una incursión masiva, desde la ciudad de San Cristóbal de las Casas, para derribar la estatua del conquistador Diego de Mazariegos.

El libro de Fernando Matamoros enriquece nuestro conocimiento sobre las lógicas simbólicas y político-religiosas activas en la Conquista. Me parece que su aporte más importante es que, a partir de un análisis preciso y documentado, de las prácticas y discursos de los colonizadores del siglo XVI, sugiere una reflexión sobre las contradicciones de la Modernidad y de la civilización occidental. 